\title{
A Bibliometric Analysis and Visualisation of Research Trends in Orthopaedic Implants
}

\author{
Bhupinder Singh $^{\mathrm{a}}$ \\ Department of Mechanical Engineering, Chandigarh University, Garran, Punjab, \\ India. 140413
}

Article History: Received: 11 January 2021; Accepted: 27 February 2021; Published online: 5 April 2021

\begin{abstract}
Several metals are used for orthopaedic implants. The bibliometric analysis had been conducted to understand the active authors, organizations, journals, and countries involved in the research domain of "orthopaedic implants". All published articles related to "orthopaedic implants" from "Scopus", were analyzed using the VOS viewer to develop analysis tables and visualization maps. This article had set the objective to consolidate the scientific literature regarding "orthopaedic implants" and also to find out the trends related to the same. The most active journals in this research domain were the Biomaterials. The most active country was the United States of America. The leading organization engaged in research regarding Orthopaedic implants was the IRCCS Rizzoli Orthopaedic Institute, Bologna of Italy. The most active authors who had made valuable contributions related to dental implants were Arciola C.R and Webster T.J.
\end{abstract}

Keywords: Orthopaedic-implants, Material engineering, Bibliometric analysis, VOS viewer,

\section{Introduction}

An engineered medical device to replace a missing or damaged joint or bone is known as an orthopaedic implant. Various types of orthopaedic implants and practices are widely used in the medical world. Orthopaedic implants are often used subjected to wear and corrosion and ultimately lead to poor performance, pain, and wastage of money. Similarly, various types of surface treatments and surface coatings can be conducted on orthopaedic implants to improve their competency to be used as a material for orthopaedic-implants. Material engineering and surface engineering can play a significant role in the development of new types of orthopaedic implants; and in enhancing the performance of orthopaedic implants. Patient-specific orthopaedic implants are the trends of the day and can improve the performance and reduce the cost of implant (Haglin et al., 2016)

Sol-gel coating (Balestriere et al., 2020)(Ballarre et al., 2012)(Ballarre et al., 2013)(Ballarre and Ceré, 2018) Silver coating (Devasconcellos et al., 2012); Nanostructured Forsterite (Mg2SiO4) coating (Kheirkhah et al., 2015); Hydroxyapatite/hydroxyapatite-magnesium double-layer coatings (Rezaei et al., 2020)(Sutha et al., 2015); (Shibli and Jayalekshmi, 2008) are various surface coating procedures and surface modifications to improve performance of implants. The carcinogenic potential of Cobalt-based implants is an important issue to be addressed and this problem can be handled by sol-gel hybrid coatings in cobalt-based implants (Amato et al., 2005). High chemical stability, mechanical strength, and biocompatibility make Titanium an attractive metal for implants (Elias et al., 2005)(Han et al., 2009) (Jemat et al., 2015). Better anti-bacterial ability to Titanium implants can be given by silver coating (Bitika, Uzuna and Keçika, 2013). Increasing surface roughness (Elias et al., 2005)(Jemat et al., 2015) and thickness of Titanium oxide layer are possibilities for increasing biocompatibility of Titanium-based implants (Elias et al., 2005). Various types of mechanical, chemical and electrochemical surface preparation methods like electrolytic polishing and ultrasonic cleaning can resist the corrosion of steel implants and reduce the breakdown potential.

This bibliometric analysis will be a useful platform for future researchers by realizing the top researchers, organizations, and countries involved in research regarding Orthopaedic implants. This article is arranged into four sections. The first section is the introduction, followed by the discussion of the methodology by which the research was conducted. The third section deals with results and discussion. The fourth section deals with the conclusion. The following research objectives and research questions were framed for conducting bibliometric analysis systematically.

\subsection{Research Objectives}

a) To consolidate the literature regarding Orthopaedic implants

b) To find out the trends related to research in Orthopaedic implants

\subsection{Research Questions}

a) Who are the active researchers working on Orthopaedic implants?

b) Which are the main organizations and countries working on Orthopaedic implants? 
c) Which are the main journals related to Orthopaedic implants?

\section{Research Methodology}

Scopus files had been used for this article. For the article selection, the Boolean used was TITLE (Orthopaedic implant) on 11/03/2021. All the tables in this paper were created by using Microsoft Excel and VOS Viewer. Grammarly was used for spelling and grammar checks. Mendeley was used for article review and citation. This paper had been inspired by bibliometric analysis in its presentation style, analysis, and methodology from the works (Farhat et al., 2013; Liao et al., 2016; Kolkailah et al., 2019; Rodríguez-Padial et al., 2019; Tran et al., 2019; Ullah et al., 2019; Shahid et al., 2020).

\section{Results and discussion}

\subsection{Results}

This first round of search produced an outcome of 1836 documents, in 23 languages, out of which 1683 documents were in English. The classification of document categories is shown in Figure 1. For improving the quality of the analysis, we had selected only the peer-reviewed articles and all other documents had not been considered. Thus after using filters "Article" and "English" the second round search produced an outcome of 1089 English articles (both open access and others). This paper had used all English articles to conduct bibliometric analysis and visualization using VOS Viewer. The English research articles in this domain since 1961 had been shown in Figure 2.

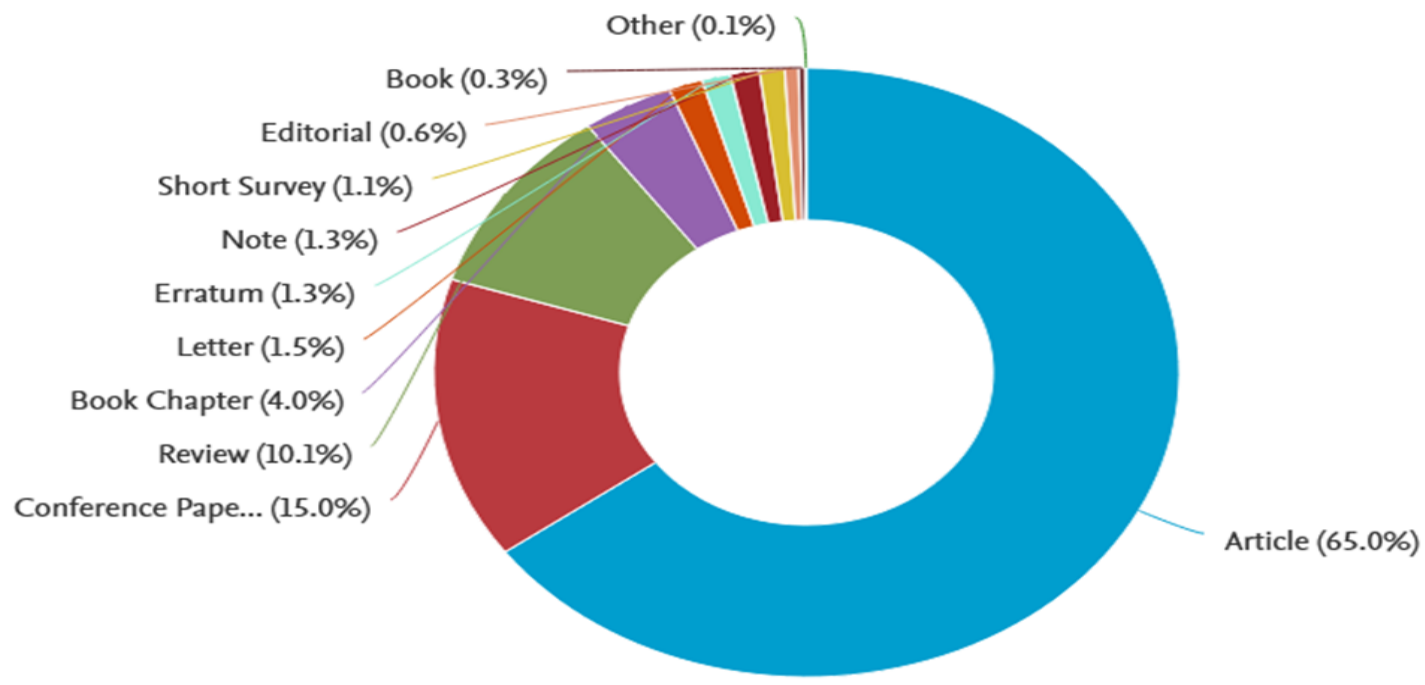

Figure 1: Classification of the documents on "orthopaedic implants", Source: www.scopus.com

100

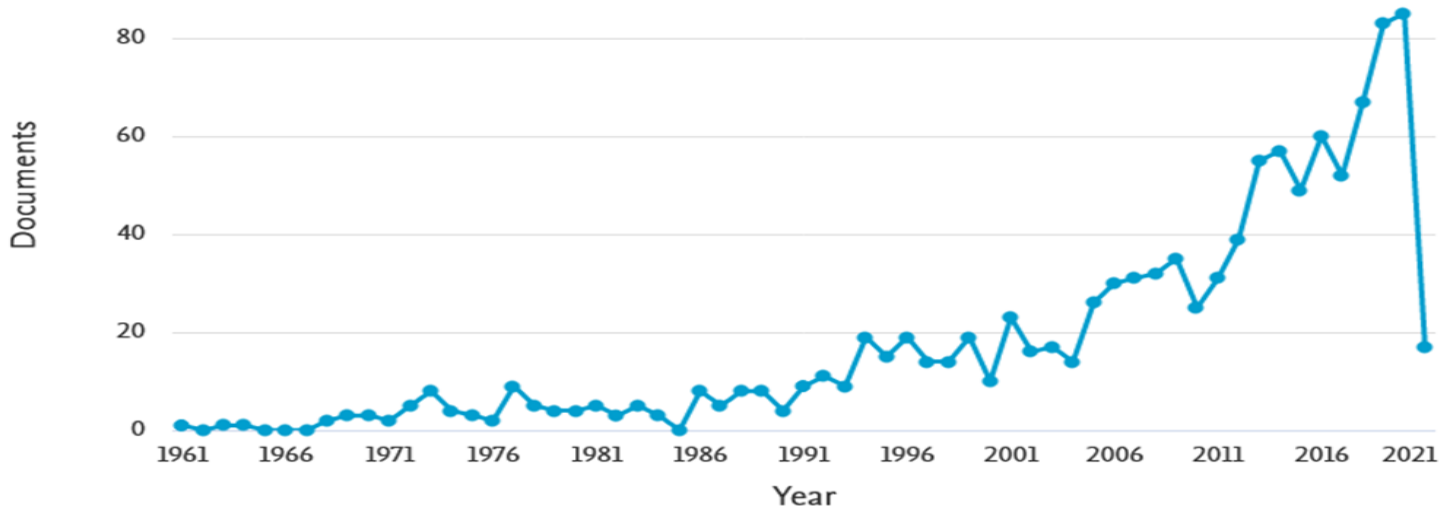

Figure 2: Period wise publication of articles, Source: WWW.scopus.com

Co-authorship analysis of top authors had been shown in figure 3. For a better presentation of the analysis, the parameters used were the minimum number of documents of an author as six and the minimum number of citations of authors as one. This combination plotted the map of 22 authors, in seven clusters. The overlay visualization map of co-authorship analysis plotted in Figure 3, points out the major researchers with their strong co-authorship linkages and clusters involved. 


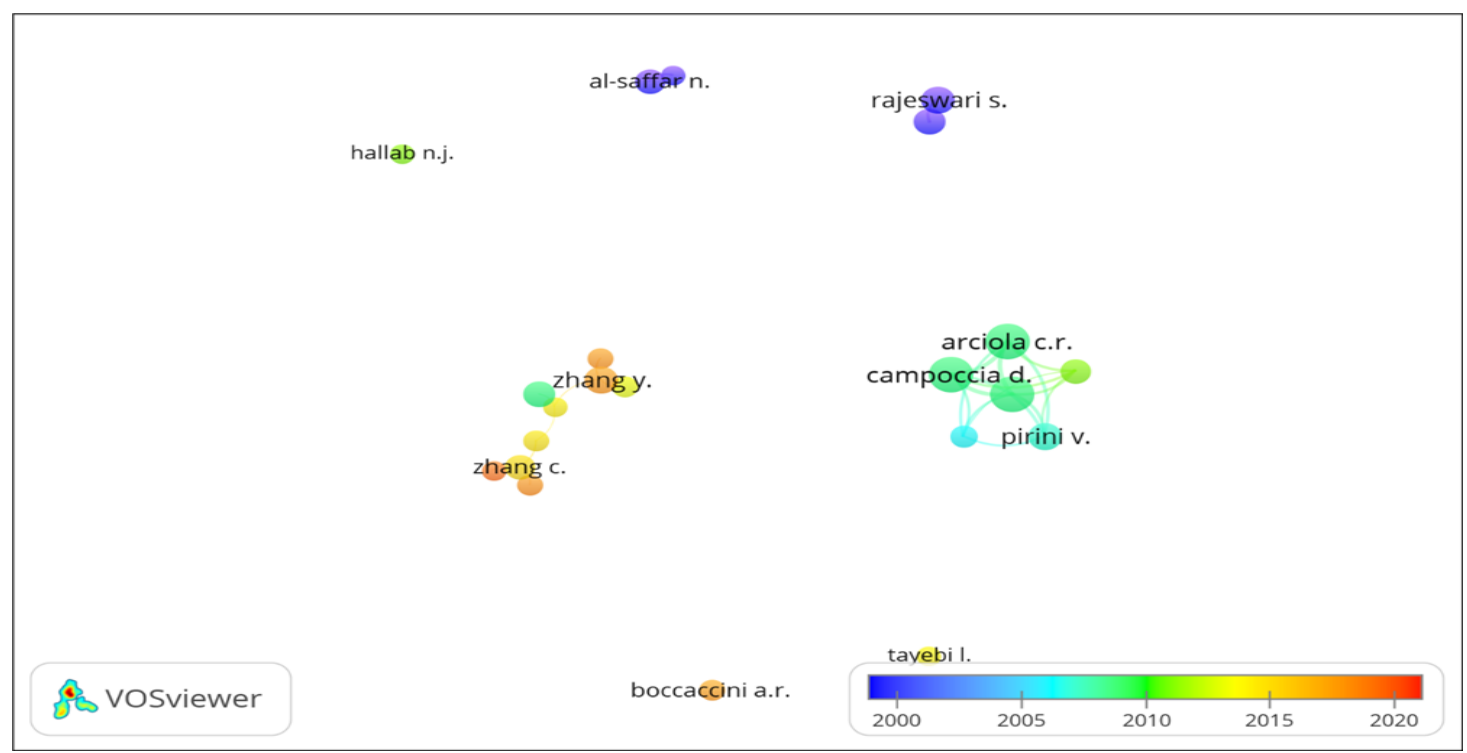

Figure 3: Co-authorship analysis on basis of authors

The citation analysis of top authors had been shown in table 1, along with co-authorship links. For the citation analysis, the parameters used were the minimum number of documents of an author as one and the minimum citations of an author as one.

Table 1: Highlights of most active authors

\begin{tabular}{|c|r|r|r|r|r|}
\hline Description & Authors & Documents & Citations & $\begin{array}{c}\text { Average } \\
\text { citations per } \\
\text { documents }\end{array}$ & $\begin{array}{r}\text { Link } \\
\text { strength }\end{array}$ \\
\hline $\begin{array}{l}\text { Authors with the } \\
\text { highest publication } \\
\text { and co-authorship } \\
\text { links }\end{array}$ & Arciola C.R & & & & \\
\hline $\begin{array}{l}\text { Authors with the } \\
\text { highest citations }\end{array}$ & Webster T.J. & 19 & 797 & 42 & 109 \\
\hline
\end{tabular}

In Co-occurrence analysis, we had used all keyword analyses, by keeping the minimum number of occurrences of a keyword as 100. This combination plotted the map of 23 thresholds, in three clusters. The overlay visualization of co-occurrence analysis of keywords has been shown in Figure 4.

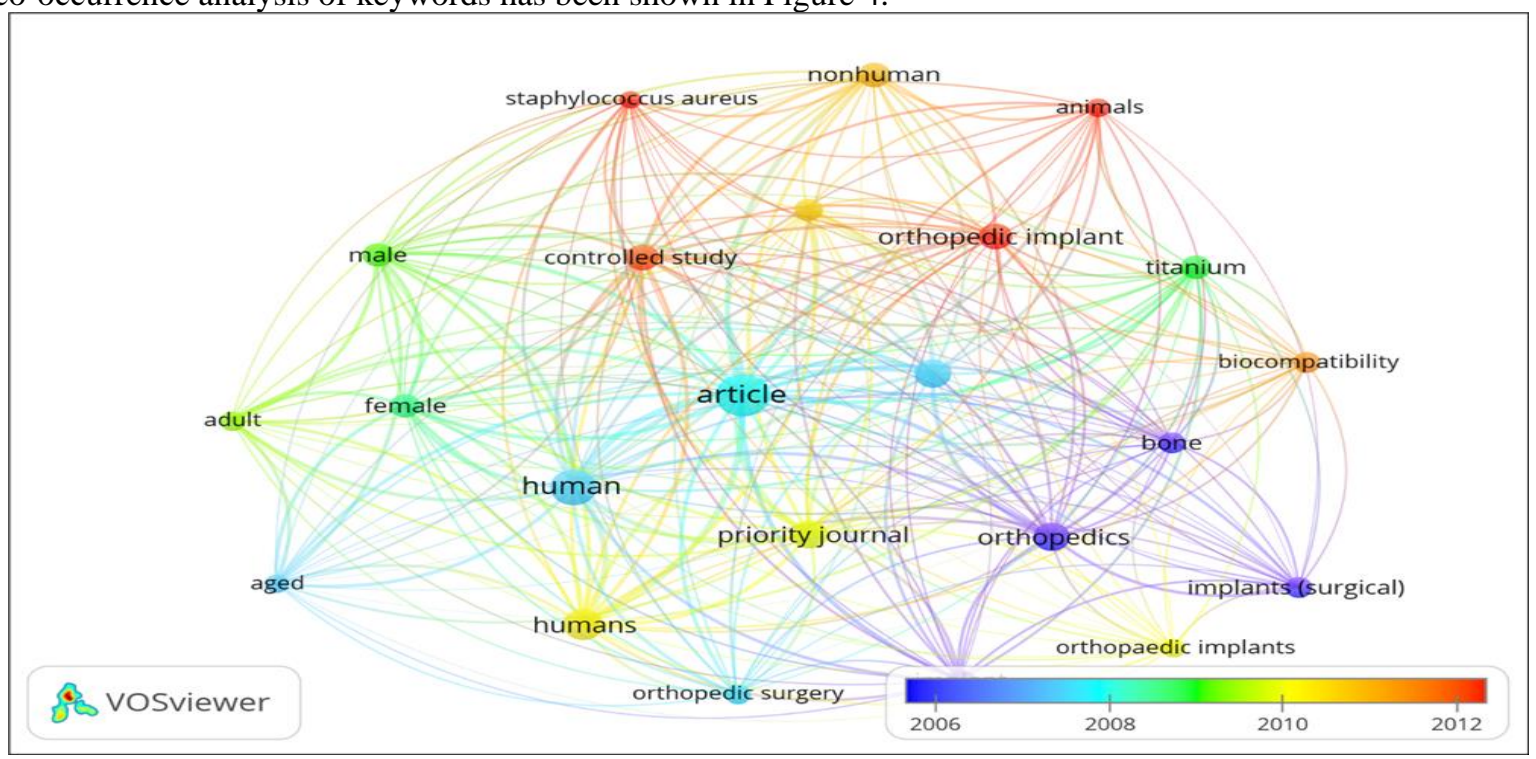

Figure 4: Co-occurrence analysis on basis of all keywords

The leading organizations engaged in research on "orthopaedic implants" had been found out by the volume of publications and citation analysis, the parameters used are the minimum number of documents of an organization as one and the minimum number of citations of organizations as one. The leading organization in the research 
regarding "orthopaedic implants", with the highest number of publications and citations, was the IRCCS Rizzoli Orthopaedic Institute, Bologna of Italy (Refer to table 2).

Table 2: Highlights of the most active organization

\begin{tabular}{|l|c|c|c|c|}
\hline \multicolumn{1}{|c|}{ Organizations } & Country & s Document & Citatio & $\begin{array}{l}\text { Average } \\
\text { Citations } \\
\text { per } \\
\text { document }\end{array}$ \\
\hline $\begin{array}{l}\text { IRCCS Rizzoli Orthopaedic } \\
\text { Institute, Bologna }\end{array}$ & Italy & 24 & 111 & 46.25 \\
\hline
\end{tabular}

Co-authorship analysis of the countries engaged in the research on "orthopaedic implants" had been shown in Figure 5. The overlay visualization map of co-authorship analysis plotted in Figure 5, points out the main countries with their strong co-authorship linkages and clusters involved.

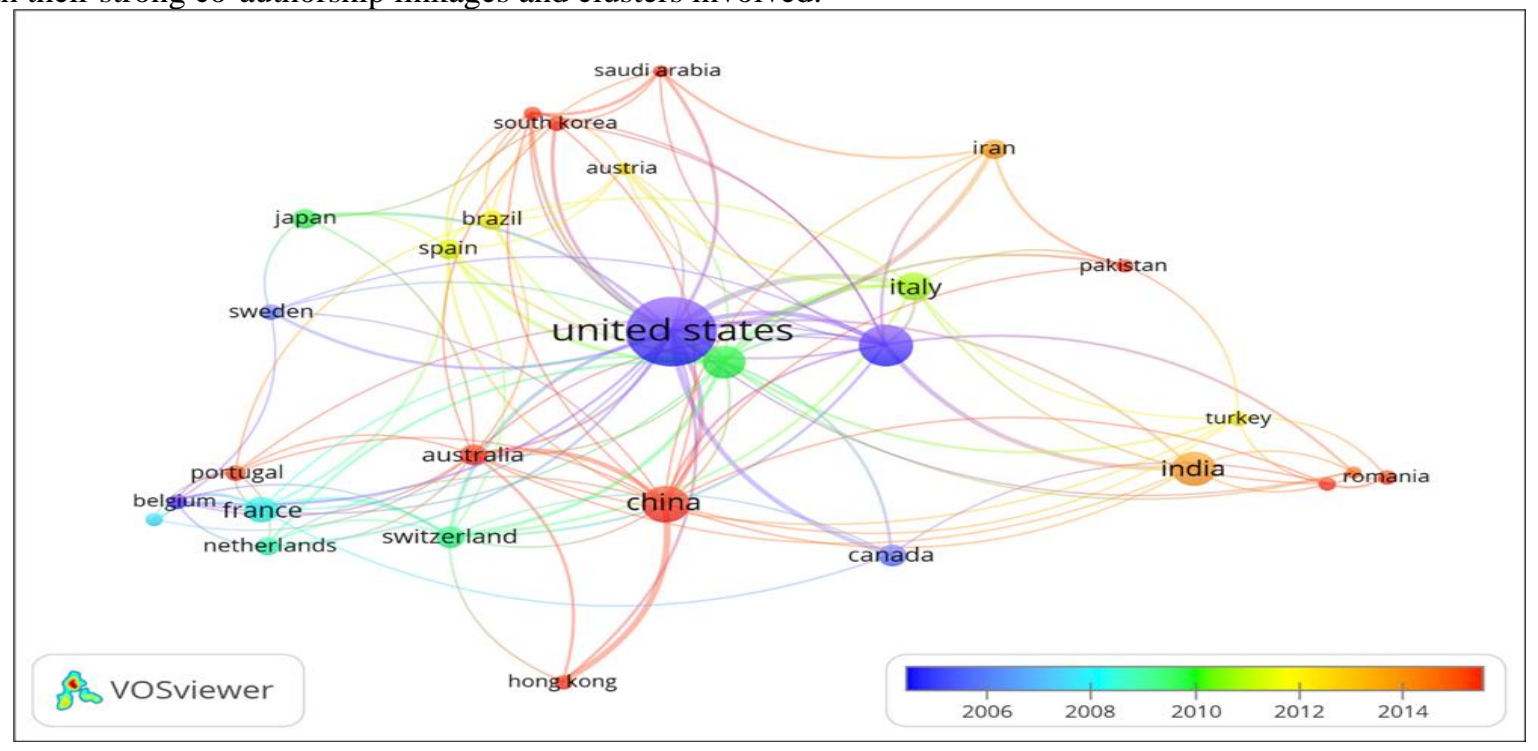

Figure 5: Co-authorship analysis on basis of countries

The citation analysis of top countries had been shown in table 3, along with co-authorship links. For the citation analysis, the parameters used were the minimum number of documents of a country as one and the minimum citations of the country as one.

Table 3: Highlights of Active Countries

\begin{tabular}{|c|c|c|c|c|}
\hline Description & Country & Document & Citation & Link strength \\
\hline $\begin{array}{l}\text { The country with the } \\
\text { highest publication, links, } \\
\text { and citations }\end{array}$ & $\begin{array}{c}\text { United States of } \\
\text { America }\end{array}$ & 302 & 11900 & 90 \\
\hline
\end{tabular}

The most active countries in this research domain were the United States of America with the highest number of publications, co-authorship links, and citations.

Link analysis and citation analysis were used to identify the most active journal in this research domain. We have taken the parameters of the minimum number of documents of a journal as one and the minimum number of citations of a journal as one for the link analysis and citation analysis. Highlights of the most active and relevant journals related to "orthopaedic implants" are shown in table 4 . Table 4 shows the journal activity of this research domain through parameters of publication volume, citations, and co-authorship linkages.

Table 4: Analysis of journal activity

\begin{tabular}{|r|r|r|r|r|r|}
\hline Description & Journal details & Documents & Citations & $\begin{array}{l}\text { Average } \\
\text { citations } \\
\text { per } \\
\text { documents }\end{array}$ & Links \\
\hline $\begin{array}{r}\text { Journal with the } \\
\text { highest publications, }\end{array}$ & Biomaterials & 31 & 3346 & 41.79 & \\
\hline
\end{tabular}


co-authorship links,

and citations

From the above discussion regarding the bibliometric patterns in the research regarding orthopaedic implants, this research had observed a gradual increase in research interest regarding orthopaedic implants from the starting of the millennium and the momentum is going on positively. This points out the relevance and potential of this research domain (Refer to Figure 2). The most active authors in this research domain were Arciola C.R and Webster T.J. with the highest publication, co-authorship links; and citations respectively (Refer to table 1). The overlay analysis of top countries researching orthopaedic implantations indicates that the United States of America was the leading country relating to the highest number of publications citations, co-authorship links (Refer to figure 5). The top journals of this research domain were identified as the Biomaterials with the highest number of publications, citations, and links. From these wide sources of information, researchers can focus on top journals where they can identify the most relevant and highly cited articles regarding orthopaedic implants.

\section{Conclusion}

The orthopaedic implant was an interesting research domain and the most active journals related to this research domain were the Biomaterials. The most active country was the United States of America. The leading organization engaged in research regarding Orthopaedic implants was the IRCCS Rizzoli Orthopaedic Institute, Bologna of Italy. The most active authors who had made valuable contributions related to dental implants were Arciola C.R and Webster T.J. This research domain offers a new avenue for researchers and future research can be on innovations in orthopaedic implants.

\section{References}

1. Amato, L. E. et al. (2005) 'Electrochemical characterization of sol-gel hybrid coatings in cobalt-based alloys for orthopaedic implants', Materials Letters, 59(16), pp. 2026-2031. doi: 10.1016/j.matlet.2005.02.010.

2. Balestriere, M. A. et al. (2020) 'Sol-gel coatings incorporating borosilicate bioactive glass enhance anticorrosive and surface performance of stainless steel implants', Journal of Electroanalytical Chemistry, 876. doi: 10.1016/j.jelechem.2020.114735.

3. Ballarre, J. and Ceré, S. M. (2018) Bioactive silica-based coating on stainless steel implants, Handbook of Sol-Gel Science and Technology: Processing, Characterization and Applications. Springer International Publishing. doi: 10.1007/978-3-319-32101-1_140.

4. Ballarre, J. et al. (2012) 'Enhancing low cost stainless steel implants: Bioactive silica-based sol-gel coatings with wollastonite particles', International Journal of Nano and Biomaterials, 4(1), pp. 33-53. doi: 10.1504/IJNBM.2012.048216.

5. Ballarre, J. et al. (2013) 'Bone quality around bioactive silica-based coated stainless steel implants: Analysis by Micro-Raman, XRF and XAS techniques', Journal of Structural Biology, 184(2), pp. 164172. doi: 10.1016/j.jsb.2013.09.016.

6. Bitika, O., Uzuna, H. and Keçika, A. (2013) 'In-vivo analysis of antibacterial silver coated titanium implants in a contaminated rabbit knee model [Antibakteriyel gümüş kapli\{dotless\} titanyum İmplantlari\{dotless\}n kontamine tavşan diz modelinde İn-vivo analizi]', Turkiye Klinikleri Journal of Medical Sciences, 33(6), pp. 1462-1472. doi: 10.5336/medsci.2013-37380.

7. Devasconcellos, P. et al. (2012) 'Antimicrobial particulate silver coatings on stainless steel implants for fracture management', Materials Science and Engineering C, 32(5), pp. 1112-1120. doi: 10.1016/j.msec.2012.02.020.

8. Elias, C. N. et al. (2005) 'Surface modification of titanium dental implants by micro-arc oxidation, in Agarwal A. Dahotre N.B., S. S. M. J. J. B. C. (ed.) Surface Engineering in Materials Science III Proceedings of a Symposium sponsored by the Surface Engineering Committee of the(MPMD) of the Minerals, Metals and Materials Society, TMS. San Francisco, CA, pp. 177-183.

9. Farhat, T. et al. (2013) 'Research in congenital heart disease: A comparative bibliometric analysis between developing and developed countries', Pediatric Cardiology, 34(2), pp. 375-382. doi: 10.1007/s00246-0120466-6.

10. Haglin, J. M. et al. (2016) 'Patient-Specific Orthopaedic Implants.', Orthopaedic surgery, 8(4), pp. $417-$ 424. doi: 10.1111/os.12282

11. Han, J.-Y. et al. (2009) 'The surface modifications of dental implants that are made of a near- $\beta$ type titanium alloy', Materials Science Forum, 618 619, pp. 299-302. doi: 10.4028/www.scientific.net/MSF.618-619.299.

12. Jemat, A. et al. (2015) 'Surface modifications and their effects on titanium dental implants', BioMed Research International, 2015. doi: 10.1155/2015/791725. 
13. Kheirkhah, M. et al. (2015) 'Surface modification of stainless steel implants using nanostructured forsterite (Mg2SiO4) coating for biomaterial applications', Surface and Coatings Technology, 276, pp. 580-586. doi: 10.1016/j.surfcoat.2015.06.012.

14. Kolkailah, A. A. et al. (2019) 'Bibliometric Analysis of the Top 100 Most Cited Articles in the First 50 Years of Heart Transplantation', American Journal of Cardiology, 123(1), pp. 175-186. doi: 10.1016/j.amjcard.2018.09.010.

15. Liao, J. et al. (2016) 'The most cited articles in coronary heart disease: A bibliometric analysis between 1970 and 2015', International Journal of Cardiology, 222, pp. 1049-1052. doi: 10.1016/j.ijcard.2016.08.002.

16. Rezaei, A. et al. (2020) 'Hydroxyapatite/hydroxyapatite-magnesium double-layer coatings as potential candidates for surface modification of 316 LVM stainless steel implants', Ceramics International, 46(16), pp. 25374-25381. doi: 10.1016/j.ceramint.2020.07.005.

17. Rodríguez-Padial, L. et al. (2019) 'Trends and Bibliometric Impact of Research Grants of the Spanish Society of Cardiology/Spanish Heart Foundation (2007-2012) [Evolución e impacto bibliométrico de las becas de la Sociedad Española de Cardiología/Fundación Española del Corazón en el periodo', Revista Espanola de Cardiologia, 72(12), pp. 1012-1019. doi: 10.1016/j.recesp.2018.08.013.

18. Shahid, I. et al. (2020) 'Characteristics of highly cited articles in heart failure: A bibliometric analysis', Future Cardiology, 16(3), pp. 189-197. doi: 10.2217/fca-2019-0016.

19. Shibli, S. M. A. and Jayalekshmi, A. C. (2008) 'Development of phosphate interlayered hydroxyapatite coating for stainless steel implants', Applied Surface Science, 254(13), pp. 4103-4110. doi: 10.1016/j.apsusc.2007.12.051.

20. Shivendra Kumar, K., Meenakshi, C. V. R. and Ramana, S. V (2019) 'Nano Coatings on Knee ImplantsA Tribological Review', in Yarlagadda P.K.D.V. Jeyapandiarajan P., J. J. I.-S. K. Y.-L. C. A. X. M. (ed.) Materials Today: Proceedings. Elsevier Ltd, pp. 2088-2092. doi: 10.1016/j.matpr.2020.03.224.

21. Sutha, S. et al. (2015) 'Mg-doped hydroxyapatite/chitosan composite coated 316L stainless steel implants for biomedical applications, Journal of Nanoscience and Nanotechnology, 15(6), pp. 4178-4187. doi: 10.1166/jnn.2015.9753.

22. Tran, B. X. et al. (2019) 'The current research landscape of the application of artificial intelligence in managing cerebrovascular and heart diseases: A bibliometric and content analysis, International Journal of Environmental Research and Public Health, 16(15). doi: 10.3390/ijerph16152699.

23. Ullah, S. et al. (2019) 'Publication trends of Pakistan Heart Journal: A bibliometric study', Library Philosophy and Practice, 2019. 